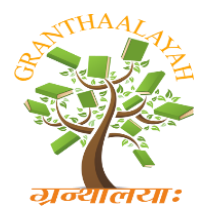

$$
\begin{gathered}
\text { INTERNATIONAL JOURNAL OF RESEARCH - } \\
\text { GRANTHAALAYAH } \\
\text { A knowledge Repository }
\end{gathered}
$$

Management

\title{
AGEING OF SERVICE PENSIONERS AND ITS IMPACT ON PENSION EXPENDITURE IN KERALA
}

\author{
Mr. M. S. Ansar ${ }^{1}$, Dr. P. Arunachalam ${ }^{2}$ \\ ${ }^{1}$ Research Scholar, Cochin University of Science \&Technology, Kochi-22, INDIA \\ ${ }^{2}$ Professor, Department of Applied Economics, Cochin University of Science \& Technology, \\ Kochi-22, INDIA
}

DOI: https://doi.org/10.29121/granthaalayah.v4.i9(SE).2016.2513

\begin{abstract}
Population of Kerala has been ageing faster compared to ageing of population in other Indian states. Service pensioners, who are part of the general population, have also been ageing in Kerala. Peculiar aspect of the ageing of service pensioners is that ageing is more pronounced in the old old and oldest old category of pensioners. Ageing of pensioners increases the number of pensioners which in turn increases the pension expenditure in Kerala.
\end{abstract}

Keywords:

Service pensioners; young old; old old; oldest old; median age; index of ageing; index of oldest old to young old; pension expenditure.

Cite This Article: Mr. M. S. Ansar, and Dr. P. Arunachalam, "AGEING OF SERVICE PENSIONERS AND ITS IMPACT ON PENSION EXPENDITURE IN KERALA", International Journal of Research - Granthaalayah, Vol. 4, No. 9: SE (2016): 82-97.

\section{INTRODUCTION}

Aging of population is pervasive as it is affecting all most all the countries of the world (UN, 2010). In many developing countries the ageing of population is faster than the ageing occurred in past in developed countries. Consequently the developing countries have to adapt quickly to ageing process (UN, 2015). The shift in age structure associated with population ageing has a profound impact on the economy and society. Rapid ageing of pensioners resulted in rapidly growing pension expenditure around the world (OECD, 2011). Fourteenth Finance Commission listed out longevity of pensioners as one of the reasons for the increasing pension expenditure of State Governments and Central Governments (GOI, 2014). In this paper an attempt is made to analyse whether the service pensioners in Kerala are ageing and it has any impact on the pension expenditure. This paper is based on the data of pensioners collected from all the pension payment treasuries in Kerala 


\section{DEFINITION OF AGEING}

Population ageing is a multidimensional phenomenon and as such providing a definition is difficult. A chronological definition of old age is often made by governments for administrative purposes. In general, 60 years has been used as a yardstick for old age (Prakash, 1999). The UN has recommended the age of 60 as the age marking the onset of aging (UN, 2003; 2010). Indian census has also used 60 as a cut-off point for classification. The 'ageing of a population' is defined in terms of the proportion of persons aged 60 and over in the total population (Gulati and Rajan, 1999). United Nations defined population ageing as the process whereby older individuals, i.e. those aged 60 years or older, account for a proportionally larger share of the total population (UN, 2010; 2015). Demographers also define the old in three categories: young old (60-69 years), old old (70-79 years) and oldest old (80 years and above) (Rajan, Mishra and Sarma, 1999).

\section{AGEING IN KERALA}

Kerala's demographic landscape has witnessed drastic changes over the past 50years. A rapid transition from high to low mortality and relatively low fertility has changed the age composition of the population of Kerala. In India, the mortality decline began in the early 1920s and fertility has been declining since the early 1970s.

Table 1: CBR, IMR, CDR and TFR of Kerala and India 1971-2013

\begin{tabular}{|l|l|l|l|l|l|l|l|l|}
\hline \multirow{2}{*}{ Year } & CBR & \multicolumn{3}{l}{ IMR } & CDR & \multicolumn{3}{c|}{ TFR } \\
& Kerala & India & Kerala & India & Kerala & India & Kerala & India \\
\hline 1971 & 31.1 & 36.9 & 58 & 129 & 9.0 & 14.9 & 4.1 & 5.2 \\
\hline 1981 & 25.6 & 33.9 & 37 & 110 & 6.6 & 12.5 & 2.8 & 4.5 \\
\hline 1991 & 18.3 & 29.3 & 16 & 80 & 6.0 & 9.8 & 1.8 & 3.6 \\
\hline 2001 & 17.3 & 25.4 & 11 & 66 & 6.6 & 8.4 & 1.9 & 3.2 \\
\hline 2006 & 14.9 & 23.5 & 15 & 57 & 6.7 & 7.5 & 1.9 & 2.7 \\
\hline 2011 & 15.2 & 21.8 & 12 & 44 & 7.0 & 7.1 & 1.8 & 2.4 \\
\hline 2012 & 14.9 & 21.6 & 12 & 42 & 6.9 & 7.0 & 1.8 & 2.4 \\
\hline 2013 & 14.7 & 21.4 & 12 & 40 & 6.9 & 7.0 & 1.8 & 2.3 \\
\hline
\end{tabular}

CBR: Crude Death Rate per 1,000 population, IMR: Infant Mortality Rate per 1,000 live births, CDR: Crude Death Rate per 1,000 population and TFR: Total Fertility Rate.

Source: SRS Statistical Report 2013 and Planning Commission, 2008.

Crude Birth Rate (CBR), Infant Mortality Rate (IMR), Crude Death Rate (CDR) and Total Fertility Rate (TFR) of Kerala were less than that of India from 1971 (see Table 1). CDR of Kerala and India was almost the same since 2011. TFR of India in 1971 was 5.2 which dipped to 2.3 in 2013. In case of Kerala it was less than 2 from 1991. Kerala achieved the net reproduction rate of one in 1987 which means a total fertility rate of 2.1 (Nair, 2010). Net Reproduction Rate is defined as a measure of the average number of daughters who will be born to women during their life time assuming a fixed age-specific fertility and mortality rate. So net reproduction rate of one means there is just replacing of mothers in the population and so it leads to zero population growth in the long run (Nair, 2010). 


\section{LIFE EXPECTANCY}

Life expectancy at birth was always higher in Kerala compared to population of India (see Figure 1). The life expectancy of our country was steadily increasing. Even though life expectancy of population of Kerala had been increasing the difference with that of population of India had been declining from 2003-07.

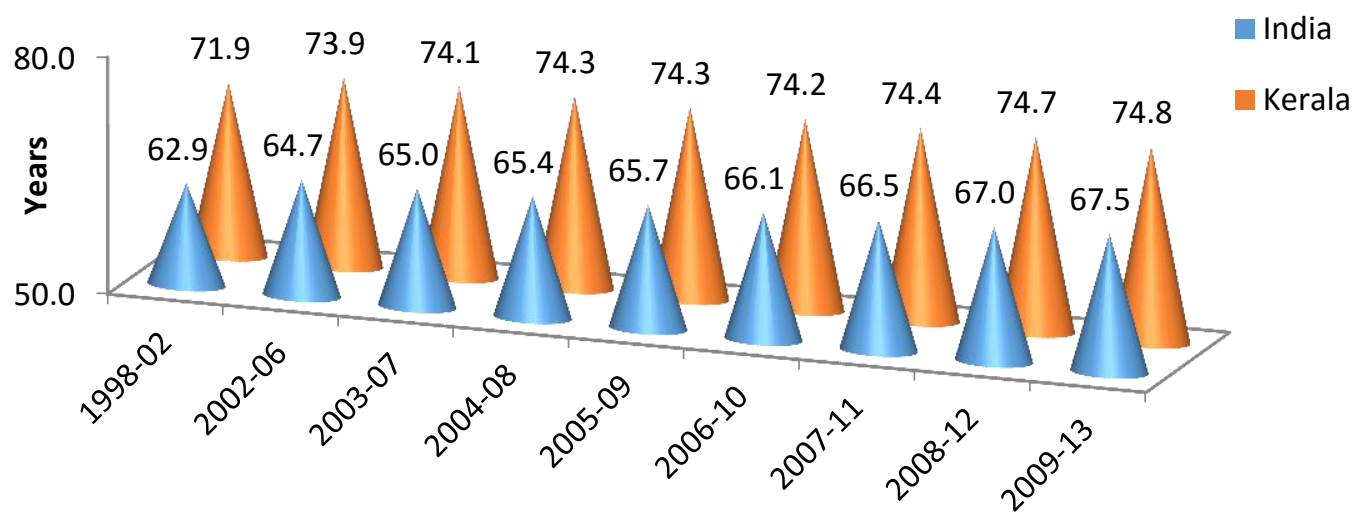

Source: Various Life tables of Registrar General of India

Figure 1: Life Expectancy of India and Kerala - 1999-03 to 2009-13

Life expectancy of the aged population in Kerala and India hadalso been increasing. The difference of life expectancy of the age groups 60-65,65-70 ad 70-75 of male population of Kerala with that of India was almost same from 2002-06 (see Table 2).

Table 2: Life Expectancy of Male Population Aged 60-80 in India and Kerala

\begin{tabular}{|c|c|c|c|c|c|c|c|c|}
\hline \multirow{2}{*}{ Period } & \multicolumn{4}{|l|}{ India } & \multicolumn{4}{|c|}{ Kerala } \\
\hline & $60-65$ & $65-70$ & $70-75$ & $75-80$ & $60-65$ & $65-70$ & $70-75$ & $75-80$ \\
\hline 1998-02 & 16.2 & 13.2 & 10.8 & 8.7 & 16.5 & 13.4 & 10.5 & 8.2 \\
\hline $2002-06$ & 16.6 & 13.5 & 10.9 & 8.7 & 17.6 & 14.3 & 11.4 & 9.1 \\
\hline 2003-07 & 16.5 & 13.4 & 10.7 & 8.6 & 17.7 & 14.5 & 11.5 & 9.2 \\
\hline 2004-08 & 16.6 & 13.4 & 10.7 & 8.5 & 17.8 & 14.4 & 11.4 & 9.2 \\
\hline 2005-09 & 16.5 & 13.3 & 10.6 & 8.5 & 17.7 & 14.3 & 11.3 & 9.1 \\
\hline $2006-10$ & 16.5 & 13.4 & 10.7 & 8.5 & 17.8 & 14.4 & 11.4 & 9.2 \\
\hline $2007-11$ & 16.5 & 13.4 & 10.7 & 8.6 & 17.8 & 14.4 & 11.3 & 9.0 \\
\hline $2008-12$ & 16.7 & 13.5 & 10.9 & 8.8 & 17.8 & 14.4 & 11.3 & 8.9 \\
\hline $2009-13$ & 16.9 & 13.6 & 10.9 & 8.7 & 18.0 & 14.6 & 11.4 & 8.9 \\
\hline
\end{tabular}

Source: Various Life tables of Registrar General of India.

Life expectancy of female population of Kerala was higher compared to the national figures. There was difference of about 2.5 year, about two years and more than one year in the life expectancy of female population of Kerala in the age groups 60-65, 65-70 and 70-75 respectively (see Table 3). 
Table 3: Life Expectancy of Female Population Aged 60-80 in India and Kerala (in years)

\begin{tabular}{|l|l|l|l|l|l|l|l|l|}
\hline \multirow{2}{*}{ Period } & \multicolumn{1}{l}{ India } & \multicolumn{9}{|l|}{ Kerala } \\
\cline { 2 - 9 } & $\mathbf{6 0 - 6 5}$ & $\mathbf{6 5 - 7 0}$ & $\mathbf{7 0 - 7 5}$ & $\mathbf{7 5 - 8 0}$ & $\mathbf{6 0 - 6 5}$ & $\mathbf{6 5 - 7 0}$ & $\mathbf{7 0 - 7 5}$ & $\mathbf{7 5 - 8 0}$ \\
\hline $1998-02$ & 18.1 & 14.7 & 11.9 & 9.6 & 19.8 & 15.9 & 12.3 & 9.4 \\
\hline $2002-06$ & 18.6 & 15.1 & 12.1 & 9.7 & 21.0 & 17.0 & 13.3 & 10.2 \\
\hline $2003-07$ & 18.6 & 15.1 & 12.0 & 9.6 & 21.0 & 16.9 & 13.2 & 10.1 \\
\hline $2004-08$ & 18.6 & 15.1 & 12.0 & 9.5 & 21.2 & 17.0 & 13.3 & 10.3 \\
\hline $2005-09$ & 18.5 & 15.0 & 11.9 & 9.5 & 21.1 & 16.9 & 13.2 & 10.2 \\
\hline $2006-10$ & 18.6 & 15.0 & 12.0 & 9.5 & 20.8 & 16.7 & 13.0 & 9.9 \\
\hline $2007-11$ & 18.7 & 15.1 & 12.0 & 9.5 & 21.1 & 17.0 & 13.3 & 10.1 \\
\hline $2008-12$ & 18.8 & 15.2 & 12.2 & 9.6 & 21.5 & 17.3 & 13.6 & 10.4 \\
\hline $2009-13$ & 19.0 & 15.4 & 12.3 & 9.7 & 21.6 & 17.4 & 13.7 & 10.3 \\
\hline
\end{tabular}

Source: Various Life tables of Registrar General of India.

\section{AVERAGE LIFE LOSS}

Average life loss is the average life expectancy loss due to 'premature death'. It was the lowest in Kerala for male and female during 1970-75 and during 2006-10 (Singh and Ladusingh, 2013)

Table 4: Average Life Loss: India and Kerala (in years)

\begin{tabular}{|l|l|l|l|l|}
\hline \multirow{2}{*}{ Period } & \multicolumn{3}{|l|}{ India } & Kerala \\
\cline { 2 - 5 } & Male & Female & Male & Female \\
\hline $1970-75$ & 23.6 & 25.1 & 18.3 & 18.0 \\
\hline $2006-10$ & 17.8 & 17.4 & 13.9 & 11.8 \\
\hline
\end{tabular}

Source: Singh, and Ladusingh, L., 2013.

The average life loss of female compared to that male population was high in India during 197075, but became less during 2006-10 (see Table 4). In Kerala average life loss was the lowest during the two periods. The finding of Vaupel (1986) that countries which have highest life expectancy have the lowest average life loss is true in the case of Kerala.

\section{THE ABSOLUTE NUMBER OF ELDERLY POPULATION}

The number of elderly people in Kerala had been growing during the last 50 years (see Table 5). During 1961-2011 the 80 years or moreaged population increased by 5.6 times nationally while in Kerala it was by6 times.It is expected that the oldest old population (80 years or moreaged) may increase by 1.87 times during the next 15 years in Kerala. The increase of old old (70-79 years aged) populationwas4.4 times during 1961-2011 whereas nationally it was 4.06 times. Young old population (60-69 years aged) increased nationally at a marginally higher rate than in Kerala.

Table 5: Number of Elderly Population in Kerala and India (in million)

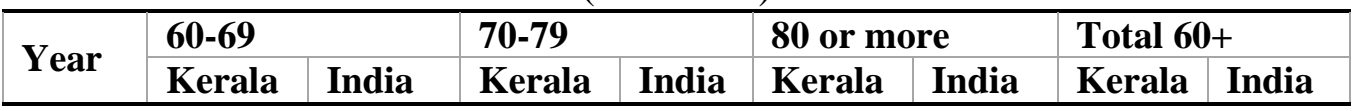




\begin{tabular}{|l|l|l|l|l|l|l|l|l|}
\hline 1961 & 0.62 & 16 & 0.28 & 7 & 0.09 & 2 & 0.99 & 25 \\
\hline 1971 & 0.83 & 22 & 0.37 & 8 & 0.13 & 3 & 1.33 & 33 \\
\hline 1981 & 1.20 & 28 & 0.53 & 11 & 0.19 & 4 & 1.91 & 43 \\
\hline 1991 & 1.56 & 35.18 & 0.71 & 14.83 & 0.29 & 6.43 & 2.56 & 56.45 \\
\hline 2001 & 1.93 & 47.32 & 1.01 & 21.26 & 0.39 & 8.04 & 3.35 & 76.62 \\
\hline 2011 & 2.42 & 64.12 & 1.23 & 28.44 & 0.54 & 11.29 & 4.19 & 103.85 \\
\hline $2016^{*}$ & 2.83 & 68.98 & 1.51 & 35.88 & 0.65 & 13.24 & 4.99 & 118.10 \\
\hline $2021^{*}$ & 3.29 & 85.54 & 1.70 & 42.04 & 0.76 & 16.67 & 5.75 & 143.25 \\
\hline $2026^{*}$ & 4.26 & 101.09 & 2.51 & 52.22 & 1.01 & 19.88 & 7.78 & 173.19 \\
\hline
\end{tabular}

Source: Up to 2011 various census; 2016 and 2021 Population Projections for India and States 2001-2026, Office of Registrar General

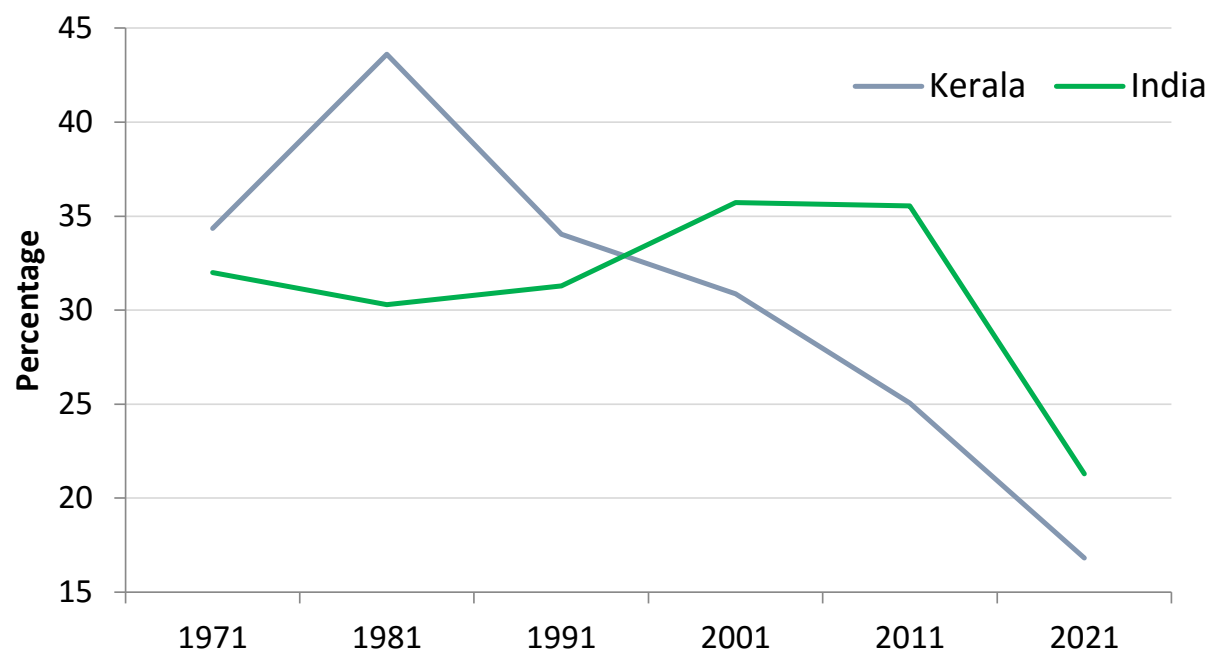

Source: Up to 2011 various census data; 2016 and 2021 Population Projection 2001-26 by Census Commissioner.

Figure 2: Decennial Growth Rates of Elderly- Kerala and India

The decennial growth rate of elderly (see Figure 2) shows fall in the growth rate in Kerala after 1981.From 2001 it became less than the national growth rate. Population Projection for India and States for 2026 made by Technical group constituted by National Commission on Population expect fall in the growth rate of elderly at the national as well as at the state level.

\section{PROPORTION OF THE ELDERLY POPULATION}

In order to know more about the ageing process a comparison of the proportion of elderly in Kerala with that of National figures is carried out. As per 1961 census figures, the proportion of 60+ years aged people was less in Kerala(see Table 6). From 1971 onwards it showed increasing tendency and it is expected to rise in the coming decades too. It is expected that in 2026 about 21 per cent of population of Kerala may be 60+ years aged while nationally it may about 12per cent. Compared to young old population, proportion of oldest old population had been increasing at a faster rate in Kerala. From less than 0.5 per cent in 1961 it increased to more than 1.62per cent in 2011 compared to the national figure of 0.93 per cent. It is estimated that in 2026, 2.71per cent population may be 80 or more aged people in Kerala. 
Table 6: Proportion of Elderly Population in Kerala and India (In Percentage)

\begin{tabular}{|l|l|l|l|l|l|l|l|l|}
\hline \multirow{2}{*}{ Year } & \multicolumn{9}{l}{$\mathbf{6 0 - 6 9}$} & $\mathbf{7 0 - 7 9}$ & \multicolumn{3}{c|}{ 80 or more } & \multicolumn{2}{l|}{ Total 60+ } \\
\cline { 2 - 9 } & Kerala & India & Kerala & India & Kerala & India & Kerala & India \\
\hline 1961 & 3.24 & 3.6 & 1.45 & 1.4 & 0.44 & 0.6 & 5.13 & 5.6 \\
\hline 1971 & 3.87 & 3.9 & 1.73 & 1.5 & 0.58 & 0.6 & 6.18 & 6.0 \\
\hline 1981 & 4.67 & 4.16 & 2.05 & 1.71 & 0.73 & 0.62 & 7.45 & 6.49 \\
\hline 1991 & 5.06 & 4.25 & 2.44 & 1.75 & 1.00 & 0.76 & 8.85 & 6.76 \\
\hline 2001 & 6.07 & 4.61 & 3.18 & 2.07 & 1.22 & 0.78 & 10.47 & 7.46 \\
\hline 2011 & 7.23 & 5.29 & 3.70 & 2.35 & 1.62 & 0.93 & 12.55 & 8.57 \\
\hline 2016 & 7.93 & 5.44 & 4.23 & 2.83 & 1.82 & 1.04 & 13.99 & 9.31 \\
\hline 2021 & 9.00 & 6.38 & 4.65 & 3.14 & 2.08 & 1.24 & 15.73 & 10.76 \\
\hline 2026 & 11.44 & 7.22 & 6.74 & 3.73 & 2.71 & 1.42 & 20.89 & 12.37 \\
\hline
\end{tabular}

Source: Up to 2011 various census data; 2016 and 2021 Population Projection 2001-26 by Census Commissioner

\section{MEDIAN AGE}

Figure5.3 shows median age of Kerala and of India from 1961 to 2021 . The increasing median age compared to national figures means population in Kerala has been ageing faster. Median age increased by about 5 years during 1961-1991 in Kerala. It is expected that compared to 1961 figure it may be doubled in 2021. There was no substantial increase in the median age of national population during 1961-2011. It is expected that median age of Indian population may be less than nearly 10 years than population of Kerala in 2021.

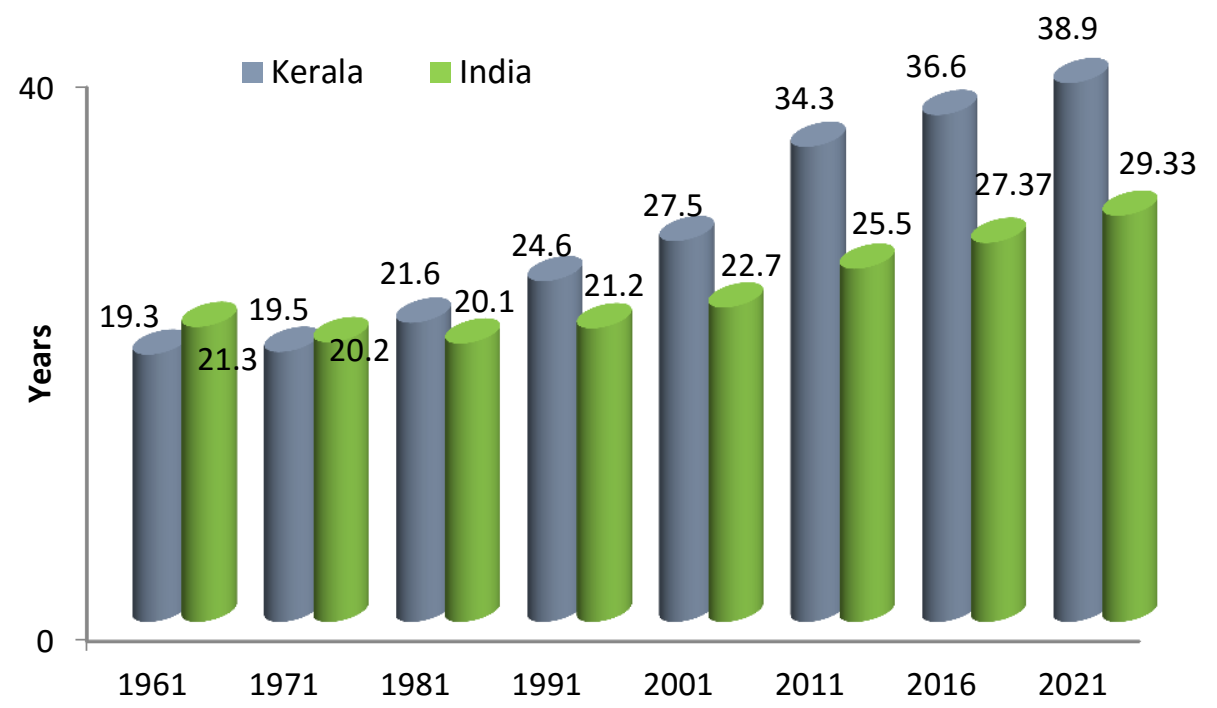

Source: Up to 2011 various census data; 2016 and 2021 Population Projection 2001-26 by Census Commissioner

Figure 3: Median Age of the Population of Kerala and India - 1961-2021

Compared to median age of male population, the median age of female population was higherin Kerala (see Table 7). As per the estimate of Zachariah and Rajan (1997) median age of female in Kerala may be about 50 in 2051. Rajan (1999) observed that as the process of ageing is more 
advanced in Kerala, the two main problems of ageing, namely, the over-whelming presence of women at the older ages and the incidence of widowhood will have to be faced.

Table 7: Median Age of Kerala 1961-2051

(in Years)

\begin{tabular}{|l|l|l|l|}
\hline Year & Male & Female & Persons \\
\hline 1961 & 18.9 & 19.8 & 19.3 \\
\hline 1971 & 19.2 & 19.7 & 19.5 \\
\hline 1981 & 21.3 & 21.8 & 21.6 \\
\hline 1991 & 24.3 & 24.8 & 24.6 \\
\hline 2001 & 26.7 & 28.1 & 27.5 \\
\hline 2011 & 33.3 & 35.2 & 34.3 \\
\hline 2016 & 35.5 & 37.6 & 36.6 \\
\hline 2021 & 37.7 & 40.0 & 38.9 \\
\hline 2026 & 40.0 & 42.5 & 41.3 \\
\hline 2031 & 41.7 & 44.7 & 43.3 \\
\hline 2036 & 42.9 & 46.6 & 45.0 \\
\hline 2041 & 43.5 & 47.8 & 45.7 \\
\hline 2051 & 45.2 & 49.4 & 47.4 \\
\hline
\end{tabular}

Source: 1961 to 2001 census figure and 2011 to 2051 Zachariah and Rajan (1997)

\section{INDEX OF AGEING}

The index of ageing which is the number of persons above age 60 per 100 children below age 14 years (UN 2003) was almost the same for Kerala and India in 1961 (see Figure 4). But from 1971 it had been increasing at a faster rate in Kerala.

The gap between the index of ageing in Kerala and in India had been widening and it is expected that the gap may be more than 55 in 2021. The index of ageing in Kerala may be as high as 476 in 2061 (Planning Commission 2008).

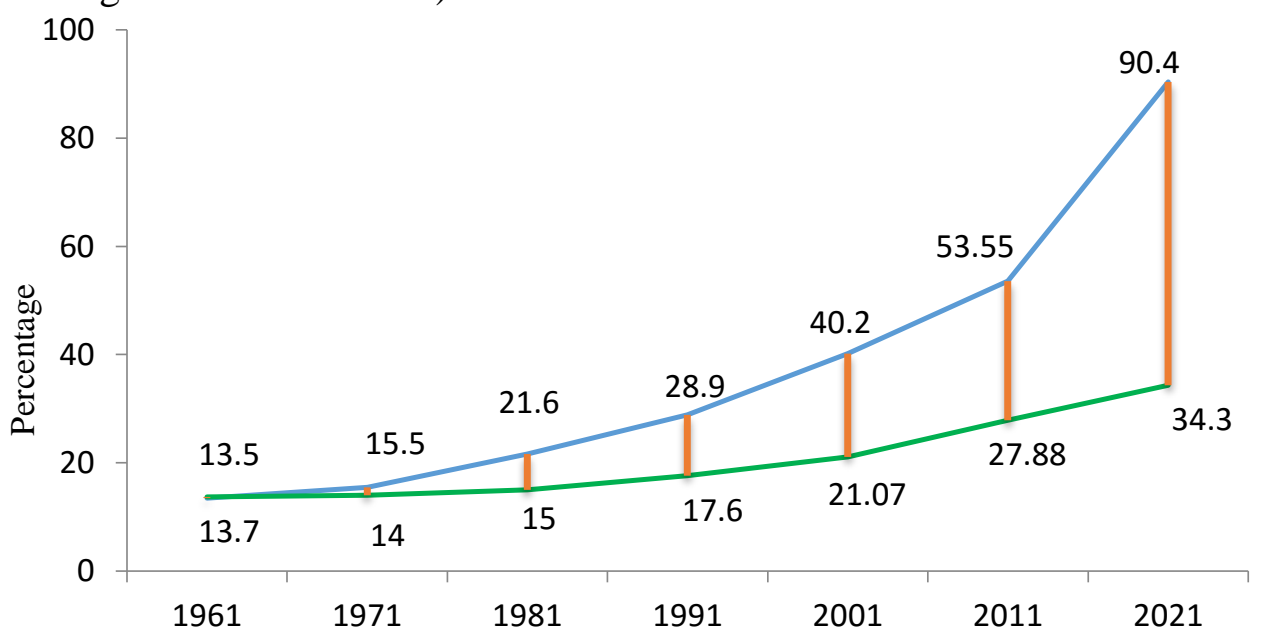

Source: Up to 2011 various census data; 2016 and 2021 Population Projection 2001-26 by Census Commissioner

Figure 4: Index of Ageing 1961-2021: India and Kerala 


\section{AGEING OF SERVICE PENSIONERS}

From the above it is evident that population of Kerala has been ageing faster than the ageing of population in India. Now analysis is needed to know whether the service pensioners who are part of the population are also ageing. For these analysis details of service pensioners such as their date of retirement, date of death, date of birth etc were collected from all the pension payment treasuries in Kerala.

\section{DEATH RATE OF SERVICE PENSIONERS}

The number of deaths of pensioners was less before 2000 as they were relatively young. The average death rate calculated from 2001-06 to 2010-2015 is given in the Table 8 .

Table 8: Average Death rate (Per 1000) of Service Pensioners 2001-2015

\begin{tabular}{|c|c|c|c|c|c|c|c|c|}
\hline \multirow[t]{2}{*}{ Year } & \multicolumn{2}{|c|}{$\begin{array}{l}\text { Less than } \\
60\end{array}$} & \multicolumn{2}{|l|}{$60-69$} & \multicolumn{2}{|l|}{$70-79$} & \multicolumn{2}{|c|}{80 or more } \\
\hline & $\mathbf{M}$ & $\mathbf{F}$ & $\mathbf{M}$ & $\mathbf{F}$ & $\mathbf{M}$ & $\mathbf{F}$ & $\mathbf{M}$ & $\mathbf{F}$ \\
\hline $2001-05$ & 3.72 & 1.61 & 9.87 & 8.44 & 19.96 & 18.00 & 52.00 & 44.36 \\
\hline $2002-06$ & 3.72 & 1.68 & 11.45 & 9.18 & 22.99 & 19.78 & 56.98 & 52.37 \\
\hline 2003-07 & 4.05 & 1.53 & 12.29 & 8.95 & 23.76 & 19.11 & 60.09 & 54.64 \\
\hline 2004-08 & 3.97 & 1.63 & 12.08 & 8.32 & 24.07 & 18.48 & 64.05 & 56.68 \\
\hline 2005-09 & 4.08 & 1.69 & 11.50 & 7.62 & & 18.47 & & 60.59 \\
\hline 2006-10 & 3.81 & 1.60 & 10.51 & 6.42 & 22.80 & 16.65 & 60.44 & 56.10 \\
\hline $2007-11$ & 3.90 & 1.52 & 9.72 & 5.62 & 21.53 & 15.15 & 56.62 & 52.63 \\
\hline $2008-12$ & 3.36 & 1.48 & 9.20 & 5.09 & 21.49 & 14.91 & 56.16 & 53.04 \\
\hline $2009-13$ & 3.37 & 1.38 & 8.56 & 4.77 & 20.76 & 14.80 & 54.82 & 51.80 \\
\hline 2010-14 & 3.15 & 1.34 & 8.25 & 4.46 & 20.64 & 14.02 & 53.18 & 49.28 \\
\hline 2011-15 & 3.03 & 1.25 & 7.70 & 4.11 & 20.08 & 13.33 & 50.47 & 46.64 \\
\hline
\end{tabular}

M-Male; F-Female

Source: Data collected from Treasuries. Calculations are made.

The average death rate of service pensioners had been declining. The fall in the death rate was more pronounced in the oldest old category especially from 2006-10.

\section{AGE PROFILE OF SERVICE PENSIONERS}

Age profile of service pensions, given in the Table 9, shows that the number of service pensioners in young old, old old and oldest old categories had been increasing. There was substantial increase in the number of old old and oldest old service pensioners during the twenty five year period.

Table 9: Age Profile of Service Pensioners 1991-2015

\begin{tabular}{|l|l|l|l|l|l|l|l|l|}
\hline \multirow{2}{*}{ Year } & \multicolumn{3}{|l|}{ Less than 60 } & \multicolumn{2}{l|}{ 60-69 } & \multicolumn{2}{l|}{ 70-79 } & \multicolumn{2}{l|}{ 80 or more } \\
& M & F & M & F & M & F & M & F \\
\hline 1991 & 17,088 & 9,673 & 15,617 & 7,413 & 3,097 & 1,242 & 188 & 94 \\
\hline
\end{tabular}




\begin{tabular}{|r|r|r|r|r|r|r|r|r|}
\hline 1996 & 25,247 & 15,375 & 29,755 & 15,077 & 7,576 & 3,376 & 754 & \multicolumn{1}{c|}{365} \\
\hline 2001 & 35,348 & 24,385 & 47,812 & 25,532 & 15,489 & 7,750 & 2,741 & 1,259 \\
\hline 2006 & 46,681 & 36,804 & 62,945 & 39,198 & 27,402 & 14,585 & 6,341 & 3,006 \\
\hline 2011 & 43,667 & 32,230 & 80,156 & 60,143 & 41,809 & 23,833 & 12,612 & 6,450 \\
\hline 2015 & 30,582 & 22,510 & 87,931 & 68,551 & 52,421 & 33,835 & 20,892 & 11,430 \\
\hline
\end{tabular}

Source: Data collected from treasuries as on 31.03.2015. Number of Pensioners as on $31^{\text {st }}$ March of each Year

Tenth State Pay Commission estimated that average number of retirees during the coming years may be 21,800 per year (GOK, 2015). Considering this estimation and assuming that the present age group wise death rate of service pensioners may continue during the coming years, the number of elderly pensioners who are under the DB pension system is estimated up to 2036 and presented in the Table 10. The number of $60+$ years aged service pensioners may increase steadily during the coming years. The number of young old pensioners is same in 2031 and 2036 due to the assumption of same death rate and retirement.

Table 10: Projected Number of Elderly Service Pensioners 2016-2036

\begin{tabular}{|l|l|l|l|l|}
\hline Year & $\mathbf{6 0 - 6 9}$ & $\mathbf{7 0 - 7 9}$ & $\mathbf{8 0}$ or more & Total \\
\hline 2016 & 153,177 & 96,480 & 38,955 & 288,612 \\
\hline 2021 & 146,561 & 129,991 & 57,519 & 334,071 \\
\hline 2026 & 180,841 & 136,449 & 82,414 & 399,704 \\
\hline 2031 & 210,145 & 131,222 & 111,289 & 452,656 \\
\hline 2036 & 210,145 & 162,622 & 120834 & 461,806 \\
\hline
\end{tabular}

Source: Estimated Figures

\section{AGE WISE PROPORTION OF SERVICE PENSIONERS}

On the basis of data collected from treasuries age group wise proportion of service pensioners was calculated and presented in the Table 11. The proportion of young old male pensioners varied between 26per cent and 31per cent during 1991-2015. The female young old pensioners expected to increase to 20.89per cent from 13.61 per cent in 1991. In the old old category female service pensioners showed 4.5 times increase.

Table 11: Age Group wise proportion of Service Pensioners

\begin{tabular}{|l|l|l|l|l|l|l|l|l|}
\hline \multirow{2}{*}{ Year } & \multicolumn{3}{l}{ 60 or less } & \multicolumn{2}{l|}{$\mathbf{6 0 - 6 9}$} & \multicolumn{7}{l|}{$\mathbf{7 0 - 7 9}$} & \multicolumn{2}{l|}{ or mote } \\
\cline { 2 - 9 } & M & F & M & F & M & F & M & F \\
\hline 1991 & 31.40 & 17.78 & 28.70 & 13.62 & 5.69 & 2.28 & 0.35 & 0.17 \\
\hline 1996 & 25.89 & 15.77 & 30.51 & 15.46 & 7.77 & 3.46 & 0.77 & 0.37 \\
\hline 2001 & 22.05 & 15.21 & 29.82 & 15.93 & 9.66 & 4.83 & 1.71 & 0.79 \\
\hline 2006 & 19.70 & 15.53 & 26.56 & 16.54 & 11.56 & 6.15 & 2.68 & 1.27 \\
\hline 2011 & 14.51 & 10.71 & 26.64 & 19.99 & 13.89 & 7.92 & 4.19 & 2.14 \\
\hline 2015 & 9.32 & 6.86 & 26.80 & 20.89 & 15.97 & 10.31 & 6.37 & 3.48 \\
\hline
\end{tabular}

Source: Data collected from Treasuries as on 31.03.2015. Calculations are made

The highest growth in the proportion was in the oldest old group. There was about 18 times increase in the case of male pensioners and about 20 times in the case of female pensioners. Besides the fact that the proportion of female service retirees was about 36per cent prior to 1999- 
2000 and less than 45per cent from 2000-01, the proportion of female service pensioners increased more than that of male service pensioners in the old old and oldest old groups. It shows that female service pensioners had been ageing faster than male service pensioners.

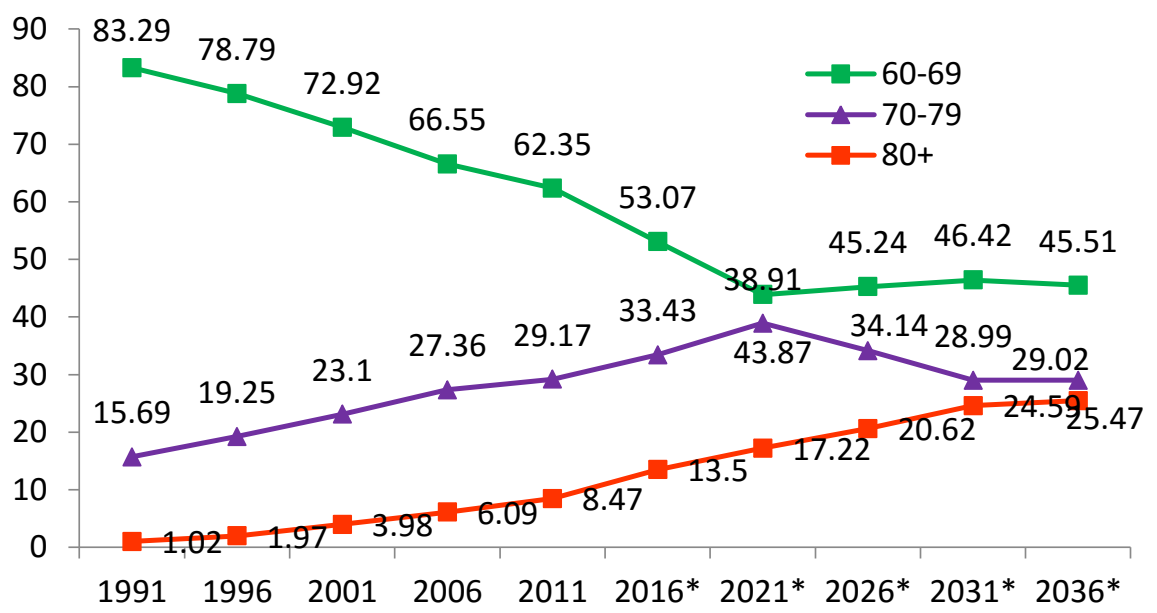

Source: Calculated figures on the basis data collected from treasuries.

*Estimated values

Figure 5: Proportion of Elderly Service Pensioners

The Figure 5 shows proportion of elderly service pensioners from 1991 to 2036. The proportion of young old service pensioners decreased sharply from more than 83per cent to 62.35per cent in 2011 and expected to fall to 38.91per cent in 2021. The sudden fall in the proportion in 2021 is due to the hike in the retirement age during 2011-12. From 2026 the proportion may increase and may reach 45.51per cent in 2036. The proportion of old old is expected to rise to about 44per cent in 2021 and may fall from 2026 due to the hike in retirement age during 2011-12. In 2036 it may increase marginally. The oldest old proportion of service pensioners shows steady increase during the 1991-2036 period and the difference between the proportion of old old and oldest old pensioners has been narrowing.

\section{MEDIAN AGE OF SERVICE PENSIONERS}

As stated above median age is an important tool for measuring ageing. The median age of pensioners especially that of female pensioners had been increasing (see Figure 6).During the twenty five year period there was about 7 years increase in the median age of pensioners.

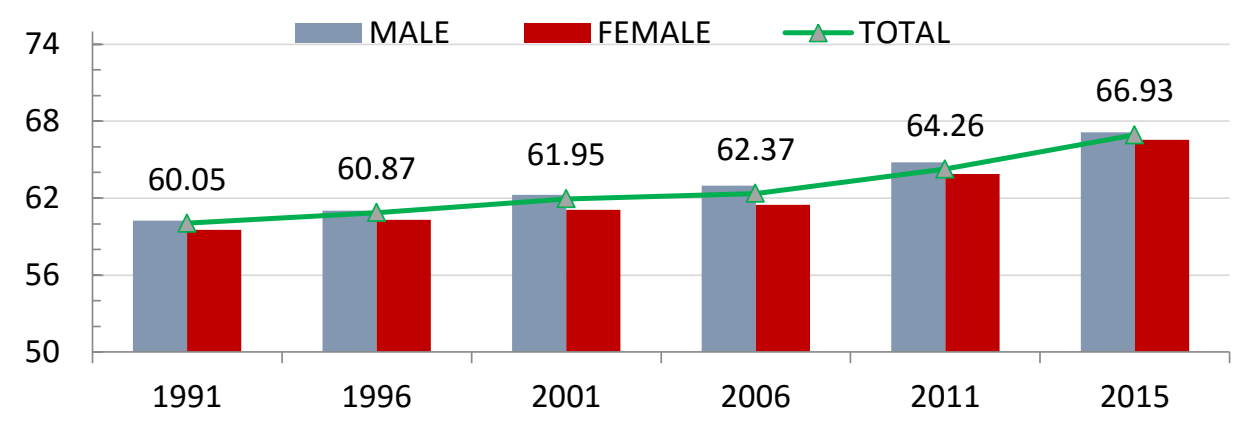

Source: Data collected from Treasuries. Calculations are made

Figure 6: Median Age of Service Pensioners (in Years) 
Median age of each age group had been increasing over the period (see Table 12). The median age of young old already crossed the age of 65 both in the case of male and female service pensioners. In the old old category median age of male service pensioner was more than 74 and that of female service pensioners was nearing 74 .

Table 12: Median age of Elderly Service Pensioner During 1991-2015

\begin{tabular}{|l|l|l|l|l|l|l|}
\hline \multirow{2}{*}{ Year } & $\mathbf{6 0 - 6 9}$ & $\mathbf{6 0 - 6 9}$ & $\mathbf{7 0 - 7 9}$ & $\mathbf{7 0 - 7 9}$ & $\begin{array}{l}\mathbf{8 0} \text { or } \\
\text { more }\end{array}$ & $\begin{array}{l}\mathbf{8 0} \text { or } \\
\text { more }\end{array}$ \\
\cline { 2 - 7 } & Male & Female & Male & Female & Male & Female \\
\hline 1991 & 63.70 & 63.50 & 72.71 & 72.45 & 82.24 & 82.33 \\
\hline 1996 & 63.24 & 63.11 & 73.21 & 73.07 & 81.92 & 82.58 \\
\hline 2001 & 64.06 & 63.90 & 73.64 & 73.32 & 82.42 & 82.58 \\
\hline 2006 & 64.16 & 63.82 & 73.15 & 73.07 & 83.25 & 83.09 \\
\hline 2011 & 64.25 & 64.03 & 73.94 & 73.77 & 83.82 & 83.56 \\
\hline 2015 & 65.00 & 65.09 & 74.17 & 73.80 & 83.82 & 83.58 \\
\hline
\end{tabular}

Source: Data collected from Treasuries. Calculations are made

The median age of old old and oldest old male service pensioners was higher than that of female service pensioners. The main reason for this disparity is the higher proportion of male pensioners in the past. Median age of oldest old service pensioners was reaching 84 and that of female service pensioners was already higher than 83.5. Rising median age of young old service pensioners was an indication that ageing process may be faster in the coming years.

\section{PROPORTION OF ELDERLY SERVICE PENSIONERS IN THE ELDERLY POPULATION OF KERALA}

In order to compare the ageing of service pensioners with population of Kerala proportionate share of elderly service pensioners in the population of Kerala aged 60+ years is calculated for 19912026 and presented in the Figure 7. From about 1 per cent of population aged 60+ years, service pensioners aged 60+ years may increase to about 6per cent in 2026. The proportionate share of oldest old increased dramatically from about 0.1 per cent in 1991 to 6.04per cent 2011 and it may be 9.66per cent in 2026. It may surpass the proportion of young old and old old service pensioners to the respective aged population in 2021. The share of old old service pensioners in old old population may be more than that of young old in 2016.

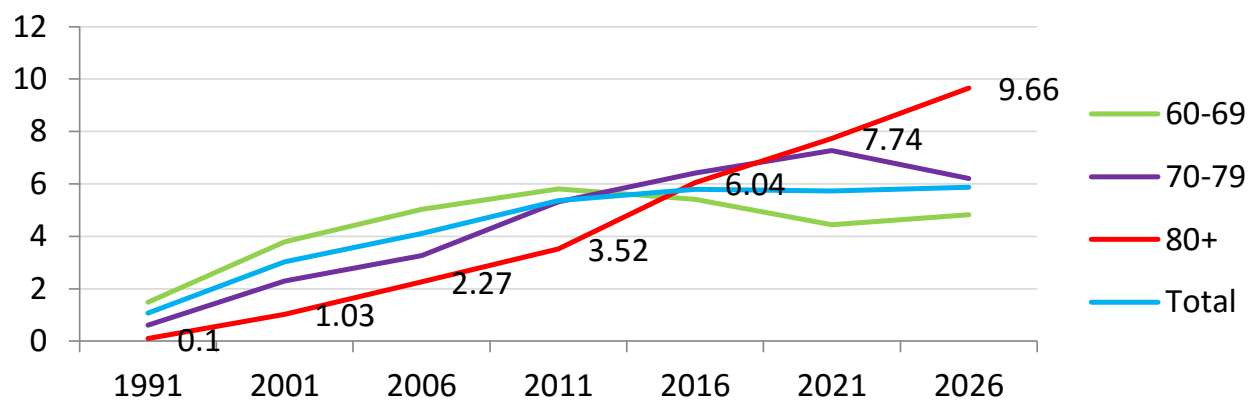

Source: Census Data, Population Projection by Census Commissioner, Data Collected from Treasuries and Estimated Number of Service Pensioners

Figure 7: Proportion of Elderly Service Pensioners in Elderly Population of Kerala During 1991-2026 


\section{INDEX OF OLDEST OLD TO YOUNGEST OLD OF SERVICE PENSIONERS}

Index of oldest old to youngest old is measuring ageing of the elderly people. It is the number of oldest old (80 years or more aged) population per 100 population aged 60-64 in a year (Planning Commission, 2008). The index of the oldest-old to the young old witnessed drastic changes in Kerala during the past 50 years. From the ratio of 23 in 1961 it increased to more than 38 in 2011 (see Table 13).

Table 13: Index of Oldest Old to Young Old - Service pensioners and Population of Kerala

\begin{tabular}{|l|l|l|}
\hline Year & Service Pensioners* & Population of Kerala $@$ \\
\hline 1991 & 1.83 & 33.26 \\
\hline 2001 & 9.10 & 37.69 \\
\hline 2011 & 23.08 & 38.30 \\
\hline 2016 & 53.89 & 40.19 \\
\hline 2021 & 75.22 & 40.73 \\
\hline 2026 & 77.25 & 41.38 \\
\hline 2031 & 104.31 & Not Available \\
\hline 2036 & 113.26 & Not Available \\
\hline
\end{tabular}

Source: *Calculated Figures; @Census Data and Population Projection by Census Commissioner

The index of oldest old to young old of service pensioners was very less in 1991, but it increased to 23.08 in 2011 and expected to increase drastically to 53.89 in 2016 and to 104.31 in 2031 . As per the estimates of Rajan and Aliyar (2009) the index of general population may reach 100 in 2061. So the estimated index of oldest old of service pensioners is very higher compared to the index of general population. It is an indication that ageing of service pensioners is faster than ageing of population in Kerala

\section{IMPACT OF AGEING OF SERVICE PENSIONERSON PENSION EXPENDITURE}

In order to know the impact of ageing on the pension expenditure of the state, age wise pension expenditure is needed. For this age wise expenditure for the ten year period from 2005-06 to 2014-15 was calculated by summing up pension amount of all service pensioners for each month. Pension of each pensioner is calculated by using the formula:

Monthly Pension=BP $+(\mathrm{BP} * \mathrm{DR})$

Where BP is the Basic Pension and DR is the Dearness Relief to pensioners.

The pension expenditure calculated for each age group is presented in the Table 14 which shows that the calculated pension expenditure had been increasing in all age groups.

Table 14: Age Group Wise Service Pension Expenditure From 2005-06 to 2014-15

\begin{tabular}{|c|c|c|c|c|c|c|c|c|}
\hline & & & & Cror & & & & \\
\hline \multirow{2}{*}{ Year } & \multicolumn{2}{|c|}{ Less than 60} & \multicolumn{2}{|l|}{$60-69$} & \multicolumn{2}{|l|}{ 70-79 } & \multicolumn{2}{|l|}{ 80-89 } \\
\hline & M & $\mathbf{F}$ & $\mathbf{M}$ & $\mathbf{F}$ & M & $\mathbf{F}$ & M & $\mathbf{F}$ \\
\hline $2005-06$ & 390.77 & 324.08 & 673.18 & 441.24 & 281.20 & 141.89 & 57.95 & 28.22 \\
\hline 2006-07 & 402.00 & 333.45 & 739.87 & 508.86 & 327.42 & 167.64 & 68.52 & 33.26 \\
\hline
\end{tabular}




\begin{tabular}{|l|l|l|l|l|l|l|l|l|}
\hline $2007-08$ & 431.96 & 344.50 & 784.82 & 567.21 & 367.22 & 191.72 & 78.82 & 38.84 \\
\hline $2008-09$ & 445.43 & 347.36 & 863.66 & 651.27 & 424.98 & 224.82 & 95.36 & 48.02 \\
\hline $2009-10$ & 481.75 & 371.72 & 1083.04 & 841.02 & 548.59 & 294.97 & 134.79 & 68.29 \\
\hline $2010-11$ & 554.86 & 416.40 & 1312.62 & 1035.13 & 675.98 & 373.44 & 168.46 & 84.46 \\
\hline $2011-12$ & 595.02 & 431.85 & 1572.23 & 1249.35 & 813.19 & 466.30 & 220.60 & 111.31 \\
\hline $2012-13$ & 573.92 & 408.78 & 1781.44 & 1419.55 & 966.01 & 577.29 & 280.63 & 143.02 \\
\hline $2013-14$ & 632.22 & 456.59 & 1926.87 & 1535.39 & 1090.93 & 681.87 & 349.38 & 183.10 \\
\hline $2014-15$ & 707.55 & 536.29 & 2164.14 & 1722.39 & 1270.23 & 830.27 & 454.78 & 240.81 \\
\hline
\end{tabular}

Source: Calculated values

While the share of pension expenditure for less than 60 years age group had been decreasing (see Table 15), the share of pension expenditure for oldest old category had been increasing for both genders during the period. During 2014-15, 15.7per cent of expenditure was for pensioners aged less than 60. 20.58per cent of calculated expenditure was for pensioners aged 60 or less. So a hike of retirement age to 60 years may reduce pension expenditure by more than 20 per cent.

Table 15: Age Group Wise Proportion of Service Pension Expenditure

\begin{tabular}{|c|c|c|c|c|c|c|c|c|}
\hline & \multicolumn{2}{|c|}{ Less than 60} & \multicolumn{2}{|l|}{ 60-69 } & \multicolumn{2}{|l|}{$70-79$} & \multicolumn{2}{|c|}{80 or more } \\
\hline & $\mathbf{M}$ & $\mathbf{F}$ & M & $\mathbf{F}$ & $\mathbf{M}$ & $\mathbf{F}$ & $\mathbf{M}$ & $\mathbf{F}$ \\
\hline $2005-06$ & 16.71 & 13.86 & 28.79 & 18.87 & 12.02 & 6.07 & 2.48 & 1.21 \\
\hline 2006-07 & 15.58 & 12.92 & 28.67 & 19.72 & 12.69 & 6.50 & 2.65 & 1.29 \\
\hline $2007-08$ & 15.40 & 12.28 & 27.98 & 20.22 & 13.09 & 6.83 & 2.81 & 1.38 \\
\hline 2008-09 & 14.36 & 11.20 & 27.85 & 21.00 & 13.71 & 7.25 & 3.08 & 1.55 \\
\hline $2009-10$ & 12.60 & 9.72 & 28.32 & 21.99 & 14.35 & 7.71 & 3.52 & 1.79 \\
\hline $2010-11$ & 12.01 & 9.01 & 28.40 & 22.40 & 14.63 & 8.08 & 3.65 & 1.83 \\
\hline 2011-12 & 10.90 & 7.91 & 28.80 & 22.88 & 14.89 & 8.54 & 4.04 & 2.04 \\
\hline $2012-13$ & 9.33 & 6.65 & 28.96 & 23.08 & 15.71 & 9.39 & 4.56 & 2.33 \\
\hline 2013-14 & 9.22 & 6.66 & 28.10 & 22.39 & 15.91 & 9.95 & 5.10 & 2.67 \\
\hline 2014-15 & 8.93 & 6.77 & 27.30 & 21.73 & 16.03 & 10.47 & 5.74 & 3.04 \\
\hline
\end{tabular}

Source: Calculated Figures

Compared to 2005-06 there was more than 850per cent and about 780per cent increase respectively in the expenditure for women and male pensioners of oldest old category (see Figure 8). This increase was very high compared to the percentage increase in the pension expenditure for the old old and young old category. Due to the ageing of service pensioners, total increase in the pension expenditure was 277.18per cent in 2014-15 from 2005-06 level.

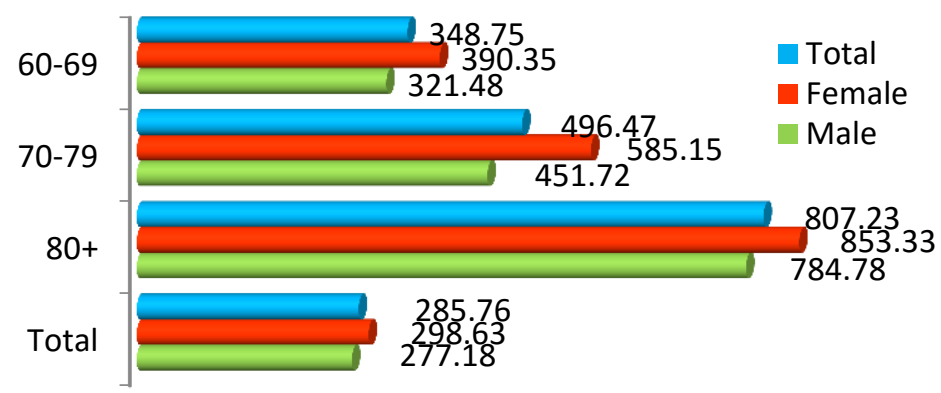

Source: Calculated Figures

Figure 8: Percentage Increase of Calculated Pension Expenditure in 2014-15 
But the increase in the calculated pension expenditure involved revision of basic pension wef 01.07.2009 due to the implementation of Ninth Pay Revision Commission Report and periodic revision of DR. So the actual impact of ageing on pension expenditure may be lower.

In order to assess the impact of ageing on pension expenditure three assumptions are made

a) There is no change in basic pension from 01/04/2005

b) There is no Dearness Relief from 01/04/2005

c) There is no retirement after 31/03/2006.

Based on above three assumptions basic pension expenditure is calculated from 2005-06 to 2014-15. As there is no retirement is assumed after 31/03/2006 the young old pensioners are considered only from the age of 65 years otherwise there shall be sharp reductions in the expenditure for young old category after 2009-10 which may lead to wrong conclusions. The calculated basic pension expenditure from 2005-06 to 2014-15 based on above three assumptions is given in the Table 16.

Table 16: Age Group Wise Basic Pension Expenditure - 2005-06 to 2014-15 (in`Crores)

\begin{tabular}{|c|c|c|c|c|c|c|}
\hline \multirow{2}{*}{ Year } & \multicolumn{2}{|l|}{$65-69$} & \multicolumn{2}{|l|}{ 70-79 } & \multicolumn{2}{|c|}{80 or more } \\
\hline & Male & Female & Male & Female & Male & Female \\
\hline $2005-06$ & 158.78 & 89.64 & 156.59 & 79.88 & 32.44 & 15.94 \\
\hline $2006-07$ & 163.31 & 97.10 & 176.36 & 91.21 & 37.04 & 18.15 \\
\hline $2007-08$ & 171.73 & 107.67 & 196.44 & 103.51 & 42.31 & 21.12 \\
\hline 2008-09 & 179.56 & 120.50 & 216.46 & 115.56 & 48.77 & 24.91 \\
\hline $2009-10$ & 191.59 & 135.89 & 233.48 & 126.61 & 57.58 & 29.51 \\
\hline 2010-11 & 206.93 & 152.60 & 250.36 & 139.80 & 66.4 & 34.25 \\
\hline 2011-12 & 227.03 & 173.24 & 267.84 & 155.30 & 76.15 & 39.44 \\
\hline $2012-13$ & 239.27 & 191.78 & 286.28 & 172.87 & 86.71 & 45.24 \\
\hline $2013-14$ & 251.77 & 207.35 & 302.36 & 190.89 & 100.49 & 53.78 \\
\hline $2014-15$ & 260.38 & 218.12 & 318.95 & 210.39 & 118.08 & 63.63 \\
\hline
\end{tabular}

Source: Calculated Figures

The basic pension expenditure for all the age groups increased but the increase in the old old and oldest old category was more glaring. In old old and oldest old group basic pension expenditure for female service pensioners increased by 2.6 times and 4 times respectively while the expenditure for male service pensioners increased by 2 and 3.6 times.

The annual growth rate of basic pension expenditure was shown in the Figure 9. The annual growth rate of expenditure for female pensioners due to ageing was higher in all age groups. 


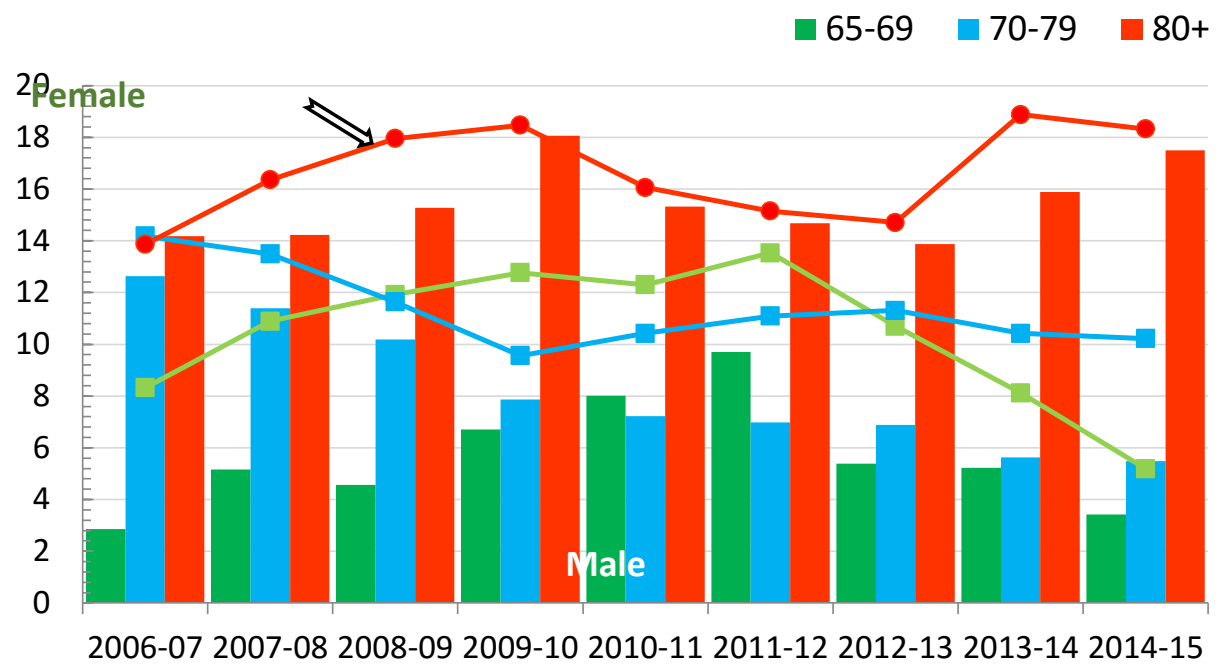

Source: Calculated Figures

Figure 9: Age and Annual Growth Rate of Calculated Basic Pension Expenditure Due to Ageing

The annual growth rate of expenditure for young old pensioners in the age group 65-69 after showing increasing tendency, decreased after 2011-12 for both male and female pensioners and became less than that of old old category. In the case of oldest old category the calculated expenditure rangedbetween about 14 per cent and 18 per cent for males and between about 13.9per cent and 18.9per cent for females. The annual growth rate of basic pension expenditure for oldest old group was higher than that of all other age groups.

Compared to the basic pension expenditure in 2005, expenditure for female oldest old pensioners increased by 314 per cent and for male service pensioners by about 273per cent(see Figure 10).

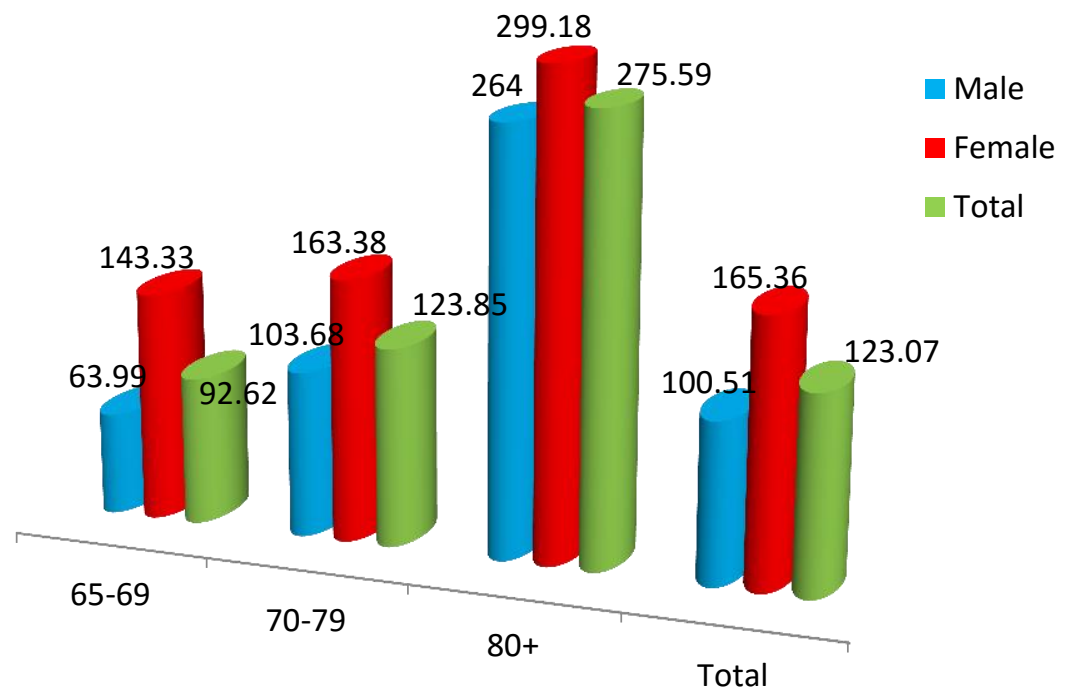

Source: Calculated Figures

Figure 10: Percentage Increase of Calculated Basic Pension Expenditure in 2014-15

The increase of about 276per cent in oldest old category was more than double than the percentage growth in old old category. Rate of growth of pension expenditure for female 
pensioners was higher in all the age groups. Ageing during the ten year period raised total pension expenditure by 150per cent in the old old and oldest old category taken together.

\section{CONCLUSION}

Service pensioners in Kerala are ageing and due to the ageing pension expenditure has been increasing particularly in the old old and oldest old category. In the coming decades increase of pension expenditure due to ageing may be higher as the ageing process may be faster as evident from the rising median age of various age groups.

\section{REFERENCES}

[1] GOI, (2014), "Report of the Fourteenth Finance Commission”, Ministry of Finance, Government of India.

[2] Gulati, Leela, and S. Irudaya Rajan, (1999), "The Added Years: Elderly in India and Kerala”, Economic and political weekly, 34(44), WS46-WS51.

[3] Golden, S. A. R. (2011). Strategy For Success Of Human Beings:-Time Management.

[4] Nair, P. Sadasivan, (2010), "Understanding below-replacement fertility in Kerala, India”, Journal of Health, Population, and Nutrition, 28(4), 405.

[5] OECD (2011), "Pensions at a Glance 2011Retirement-income Systems in OECD and G20 Countries”, Organisation for Economic Co-operation and Development, Paris.

[6] Planning Commission, (2008), "Kerala Development Report”, Academic Foundation, New Delhi.

[7] Prakash, Indira Jai., (1999), “Ageing in India”, World Health Organization, Geneva.

[8] Rajan, S. Irudaya, (1999), "Aging and Social Security”, in Kerala's Economic Development: Issues and Problems, Sage Publications India Pvt Ltd, New Delhi.

[9] Rajan, S. Irudaya, and Sabu Aliyar, (2009), "Population Ageing", in Kerala Economy Trends During the Post Reform Period (125-147), Serial Publications, New Delhi.

[10] Rajan, S. Irudaya, UmāśañkaraMiśra, and P. Sankara Sarma, (1999), "India's Elderly Burden or Challenge?”, Sage Publications, New Delhi.

[11] Singh, Akansha, and Laishram Ladusingh, (2013), "Increasing life expectancy and convergence of age at death in India”, Genus 69(1).

[12] United Nations (2003) : "Population and Development: Selected Issues", United Nations Publications, UN, New York

[13] United Nations (2003) : "Population and Development: Selected Issues", United Nations Publications, UN, New York.

[14] United Nations (2010), “World Population Prospects: The 2010 Revision”, Department of Economic and Social Affairs, Population Division, United Nations, New York..

[15] United Nations (2015), “World Population Prospects: The 2015 Revision”, United Nations, Department of Economic and Social Affairs, Population Division New York.

[16] Vaupel, James W, (1986), "How Change in Age-specific Mortality Affects Life Expectancy," Population Studies, 40(1), 147-157.

[17] Zachariah, K C, and S. Irudaya Rajan, (1997), "Kerala's Demographic Transition: An Overview”, In Kerala's Demographic Transition: Determinants and Consequences (1729), Sage Publications, New Delhi. 